\title{
Amyotrophic lateral sclerosis: clinical perspectives
}

This article was published in the following Dove Press journal:

Orphan Drugs: Research and Reviews

15 April 2015

Number of times this article has been viewed

\section{Verena $C$ Haringer Summer B Gibson}

Clinical Neurosciences Center, Department of Neurology, University of Utah School of Medicine, Salt Lake City, UT, USA

Correspondence: Summer B Gibson Clinical Neurosciences Center, Department of Neurology, University of Utah, I75 N Medical Drive East, Salt Lake City, UT 84132, USA

Tel + I 80 I585 7575

$\mathrm{Fax}+\mathrm{I} 8015824192$

Email summer.gibson@hsc.utah.edu
Abstract: Amyotrophic lateral sclerosis (ALS) is the most common motor neuron disease in adults. It is a rapidly advancing neurodegenerative disease leading to progressive paralysis and death, with a mean time of survival from onset of symptoms to death of 2-5 years. The pathophysiology of ALS remains poorly understood. The only US Food and Drug Administration-approved therapy for ALS is riluzole, a glutamatergic neurotransmission inhibitor, with modest benefits on survival. Many other agents have shown promising results in preclinical trials, but have yet to show benefit in human clinical trials. This review gives an overview of drugs that have been studied in clinical trials and their reported outcomes. This also includes more recent treatment strategies, including antisense oligonucleotides (ASOs) and stem cells. ASOs have the potential to target genes known to cause ALS by silencing their function. Many clinical trials are under way using these therapies. Different kinds of stem cells have been used in an attempt to either replace the lost motor neurons or to improve their metabolic supply and thus prolong their death. Given the limited therapeutic treatment options to date, the most important approach to improve the patient's quality of life remains symptom-based management. Additionally, we give an overview of the current treatment offered in multidisciplinary clinics.

Keywords: motor neuron disease, symptom management, treatment and experimental therapies, stem cells, antisense oligonucleotides, clinical trials

\section{Introduction}

Amyotrophic lateral sclerosis (ALS) is a fatal disease in which the upper and lower motor neurons degenerate, leading to progressive muscle weakness and eventual respiratory failure. The incidence of ALS is about 2 in 100,000. ${ }^{1}$ It generally progresses rapidly, with a mean survival time of 2-5 years following symptom onset. ${ }^{2,3}$ The clinical hallmark of the disease is death of the motor neurons leading to muscular atrophy, muscular weakness, dysarthria, and fasciculations as well as clinical findings of hyperreflexia and spasticity. The symptoms typically manifest as focal weakness in one limb; however, one-third of the cases have a bulbar presentation resulting in dysarthria, dysphagia, and respiratory dysfunction. ${ }^{4}$ About half the affected patient population will develop frontotemporal lobe dysfunction with cognitive and behavioral abnormalities and pseudobulbar affect; a subgroup of these will go on and fulfill diagnostic criteria for frontotemporal dementia (FTD). ${ }^{5}$ As there is significant overlap in the pathogenesis and genetics of FTD and ALS, ${ }^{6}$ there is growing belief that these two diseases are different phenotypes of an ALS-FTD spectrum disorder. ${ }^{7}$

It is known that the pathogenesis of ALS has a genetic component. ${ }^{3}$ While most cases of ALS are sporadic, approximately $10 \%$ of cases report a family history 
of ALS. ${ }^{8}$ Currently, about $68 \%$ of ALS patients with a family history of ALS (aka familial ALS) and 11\% of ALS patients without a known family history of ALS (aka sporadic ALS) have an identifiable genetic cause. ${ }^{3}$ The first ALS mutation, Superoxide dismutase-1 (SOD1), was discovered in 1993, ${ }^{9}$ and since then, many additional genes have been found. Mutations in SOD1 account for 10\%-20\% of familial ALS cases, and to date, $>155$ mutations have been identified. ${ }^{10}$ Two genes that play a role in the pathological findings of ALS are TAR DNA binding protein $(T A R D B P)^{11}$ and fused in sarcoma $(F U S),{ }^{12}$ which account for $\sim 5 \%$ of familial ALS cases. The GGGGCC hexanucleotide expansion of $C 9$ orf 72 is a common cause of FTD and ALS. ${ }^{13}$ This mutation is the most common known cause of both sporadic and familial ALS, responsible for about 7\% of all ALS cases in the Caucasian population. ${ }^{14}$ Mutations of many other genes have been reported, but the genetic cause of about $32 \%$ cases of familial ALS and the majority of sporadic ALS continue to be unknown. ${ }^{3}$

The pathophysiology of this devastating disease remains unclear. The pathological finding of ubiquitinated TDP-43 aggregates is found in patients who carry a mutation in the TDP-43 gene (TARDBP), as well as in ALS patients without this mutation, ${ }^{11,15}$ except in cases caused by SOD1 or FUS mutations. Similar TDP-43 aggregates are also found in FTD, leading to speculation that both diseases are variations of a spectrum of TDP-43-associated disorders. ${ }^{16}$ Although TDP-43 pathology is common to most ALS cases, the pathomechanism causing this disease is unknown. Potential contributing factors include mitochondrial dysfunction, neuroinflammation, and oxidative stress. Additionally, glutamate toxicity is thought to play a role, because ALS patients have higher levels of glutamate in serum and cerebral spinal fluid (CSF) compared to healthy controls. ${ }^{17}$

\section{Disease-modifying treatment US Food and Drug Administration-approved treatment}

Riluzole has several targets, although its proposed mechanism is as a glutaminergic neurotransmission inhibitor. It remains the only US Food and Drug Administration (FDA)-approved therapy for ALS that affects survival. Randomized trials show modest improvement in survival, possibly greater in patients with bulbar onset. ${ }^{18}$ It is likely that riluzole has less effect in advanced stage disease. ${ }^{19}$ A recent meta-analysis of all randomized controlled trials confirmed the modest increase in median survival of 2-3 months and a modest impact on functional measures. ${ }^{20}$ Given the relatively short duration of these randomized studies ( $\leq 18$ months), an analysis of ALS databases over a 5- to 10-year period was initiated, for which data are suggestive of a greater long-term improvement in survival, ranging from 6 up to over 21 months. ${ }^{20}$ Given these longer studies were not randomized, these results must be interpreted with caution.

\section{Drugs in clinical trials}

Over the past decades, a multitude of experimental pharmaceutical therapies were shown to delay disease progression in ALS animal models but failed to show efficacy in clinical trials or are still in Phase I-III trials. The mechanisms of these agents include antioxidants, neuroprotection, promotion of growth factors, antiglutamate, induction of heat shock proteins, anti-inflammatory, mitochondrial-protective agents, maintenance of muscle, and reduction of SOD1. Several drugs that have been FDA-approved for other indications are currently in clinical trials for ALS, including rasagiline, fingolimod, anakinra, and tamoxifen (http://www.clinicaltrials. gov). Of the agents that have completed clinical trials, none have been able to significantly modify disease progression or increase survival in humans with ALS (Table 1). The failure to translate from animals to humans is at least in part due to inherent limitations when using animal models to study human diseases. There are metabolic, anatomic, and cellular differences between humans and other organisms, laboratory animals are often heavily inbred, and negative study results are often not published leading to bias. Additionally, animal models often do not accurately mimic human disease. ${ }^{21}$ The most frequently used animal model to study ALS has been transgenic $S O D 1^{G 93 A}$ rodents, which have multiple copies of the human coding sequence for SOD1 with the G93A mutation. ${ }^{22}$ While this model appears to be a mimic of human ALS due to $S O D 1$ mutations, it is unclear if the results from these rodents can be applied to non-SOD1 cases of ALS. Additional rodent models of ALS are currently being studied including TDP-43 mediated, ${ }^{23}$ which have the potential to be relevant for the majority of ALS cases.

\section{Antisense oligonucleotides}

Mutations in SOD1, associated with $10 \%-20 \%$ of familial ALS cases, cause the protein to misfold, leading to toxic effects on the cellular degradation machinery and formation and accumulation of SOD1 protein aggregates. ${ }^{10}$ This results in a cellular stress response and eventual cell death, although the exact mechanism is unknown. ${ }^{10,24}$ Reduction of toxic SOD1 proteins has been proposed using antisense oligonucleotides (ASOs). ${ }^{25}$ ASOs are short, synthetic 


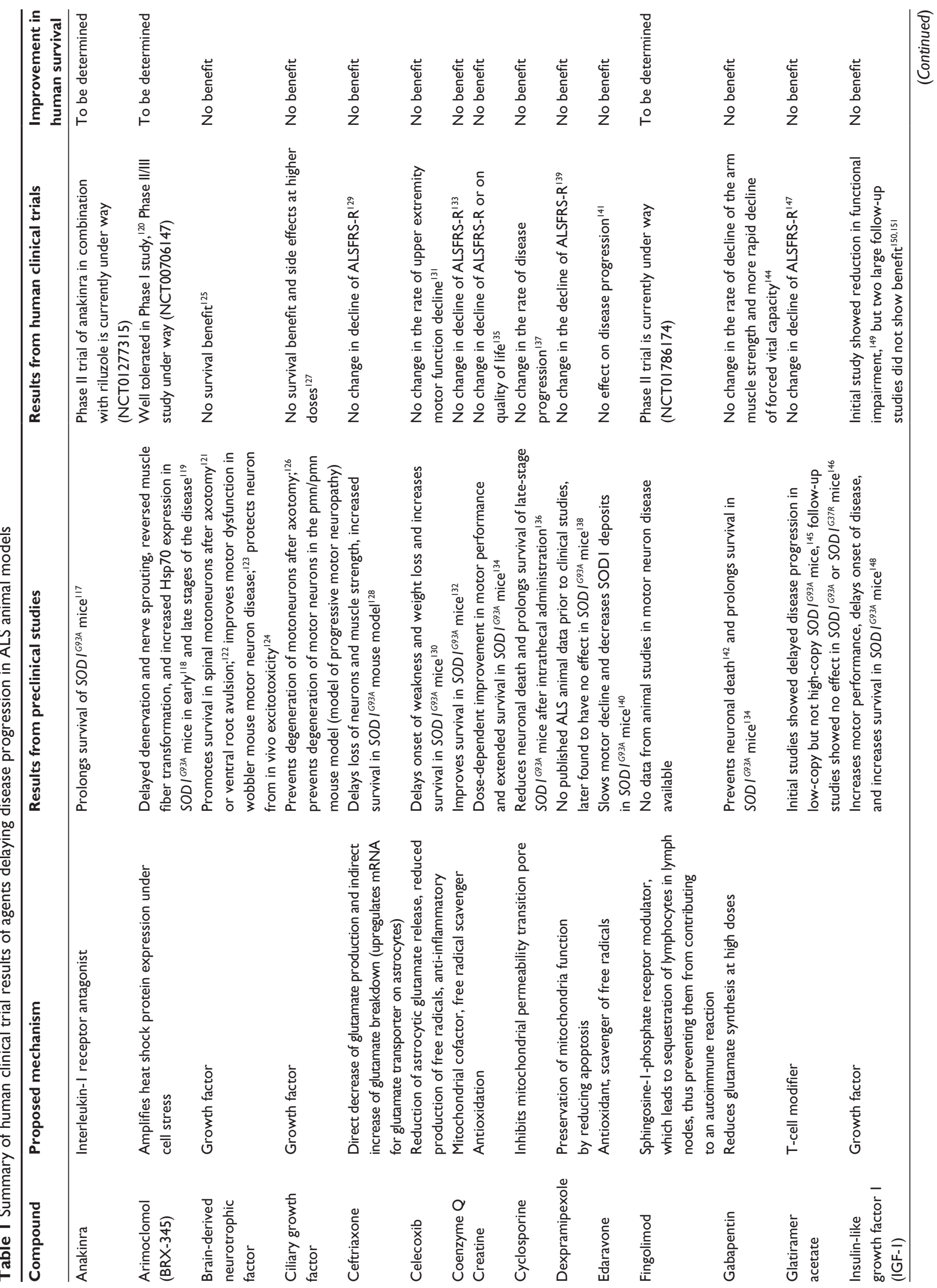




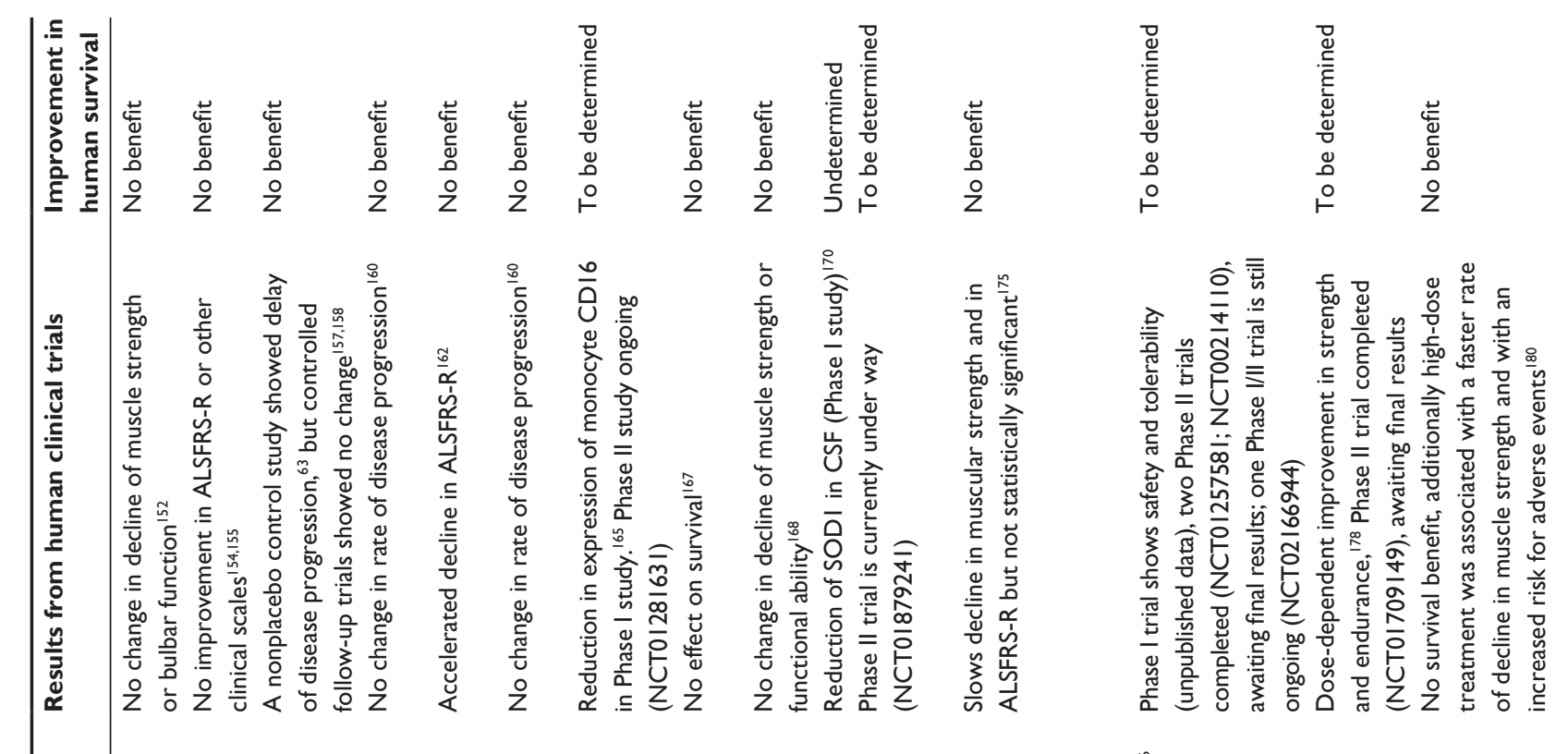

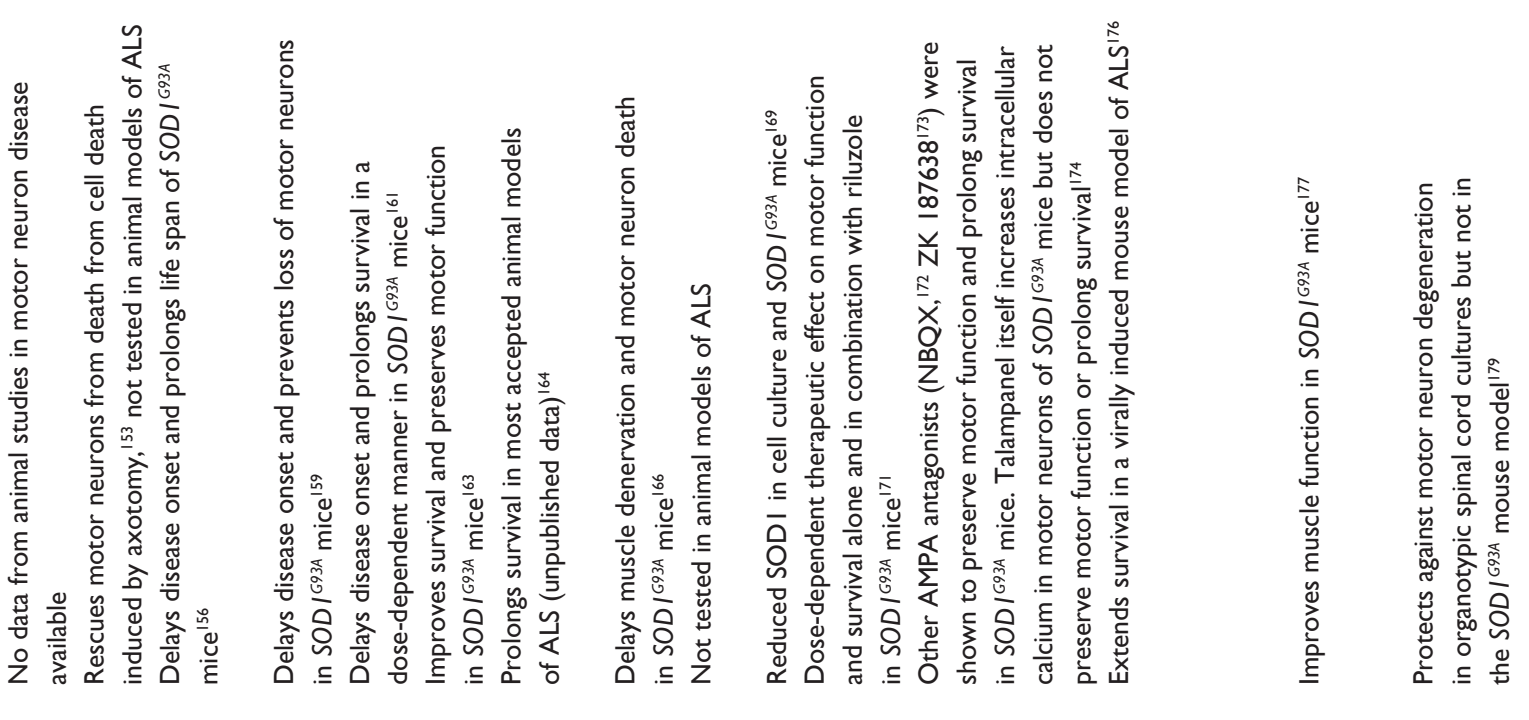

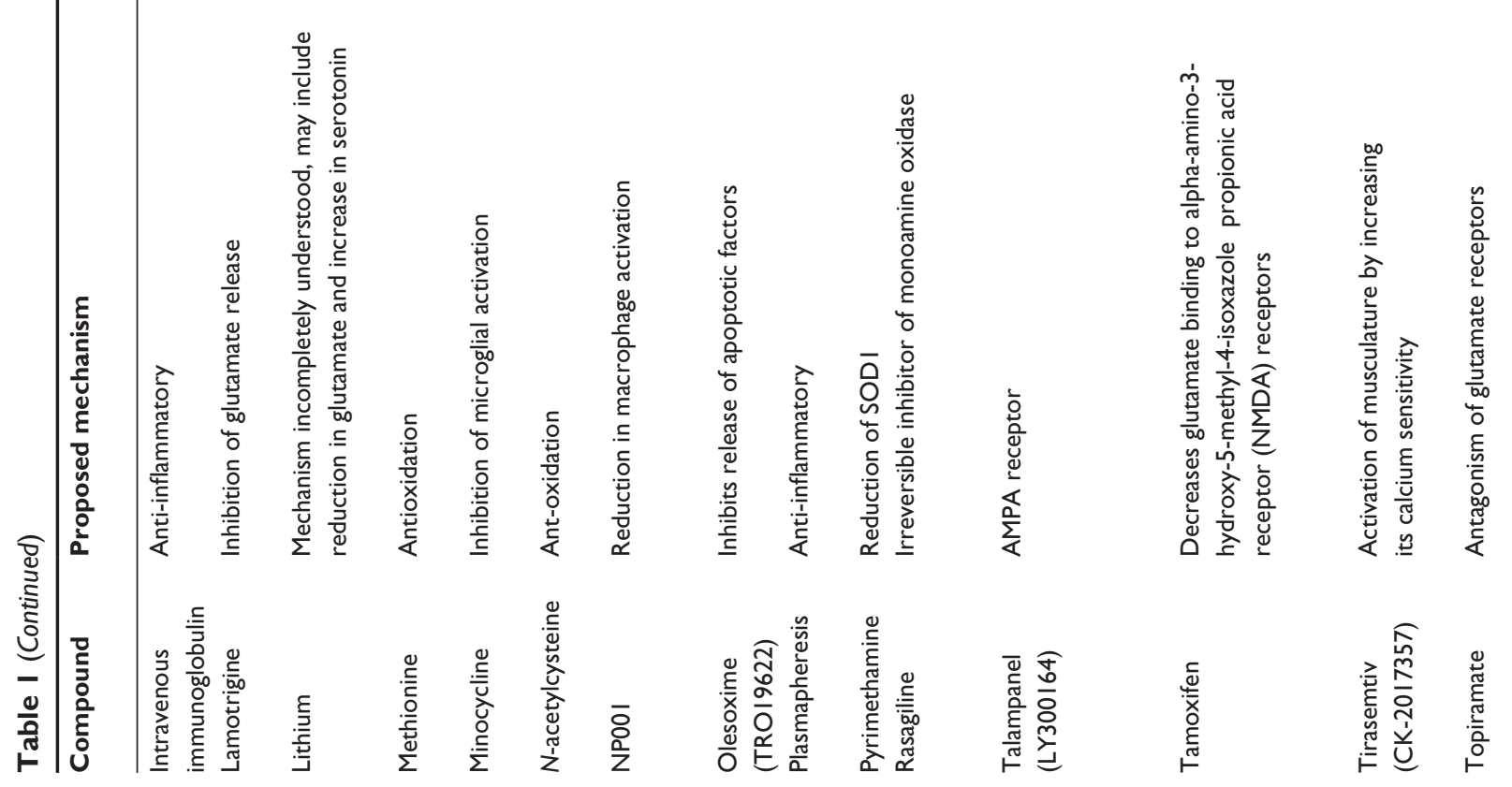




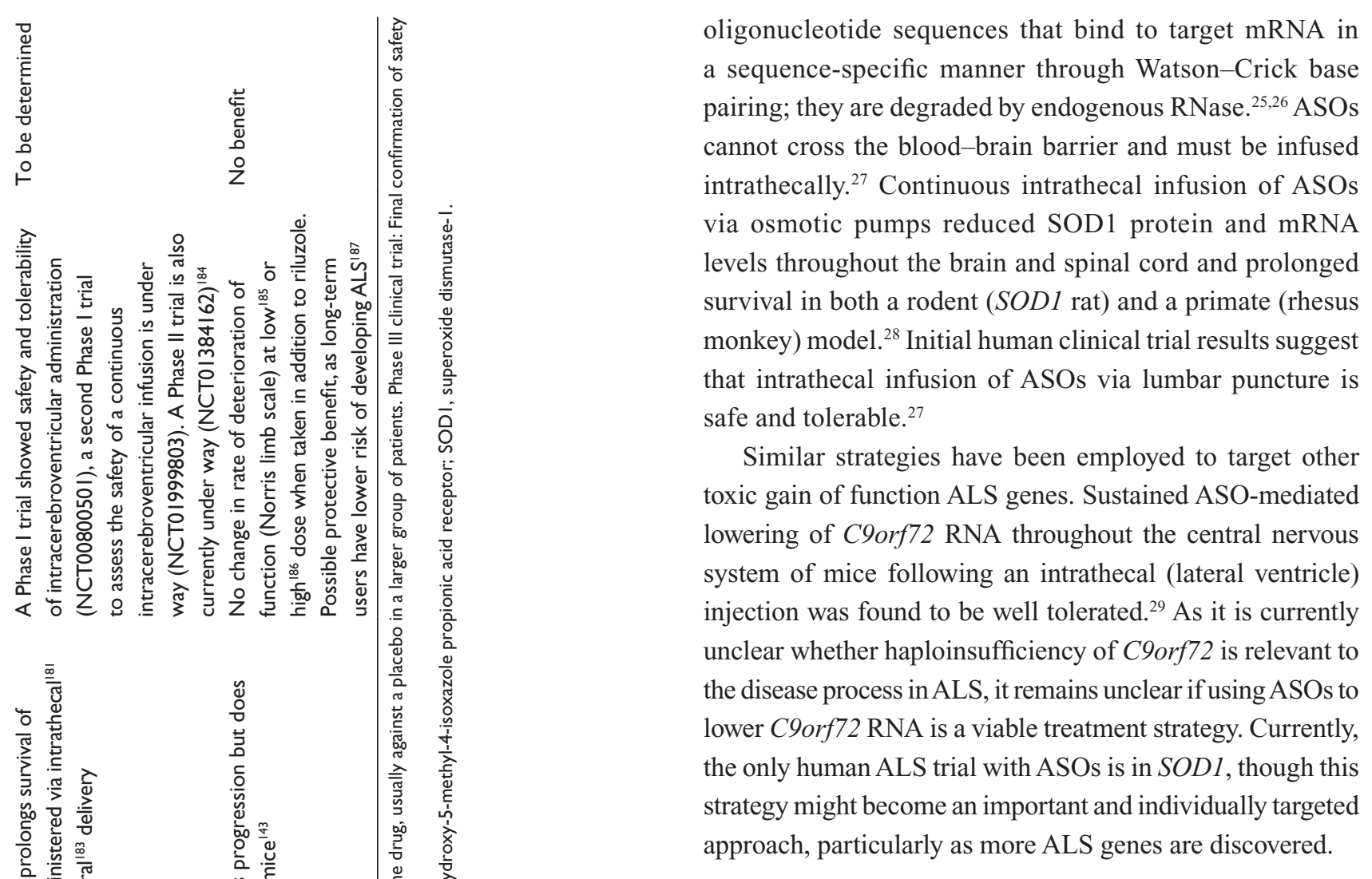

oligonucleotide sequences that bind to target mRNA in a sequence-specific manner through Watson-Crick base pairing; they are degraded by endogenous RNase. ${ }^{25,26} \mathrm{ASOs}$ cannot cross the blood-brain barrier and must be infused intrathecally. ${ }^{27}$ Continuous intrathecal infusion of ASOs via osmotic pumps reduced SOD1 protein and mRNA levels throughout the brain and spinal cord and prolonged survival in both a rodent (SOD1 rat) and a primate (rhesus monkey) model. ${ }^{28}$ Initial human clinical trial results suggest that intrathecal infusion of ASOs via lumbar puncture is and tolerable. ${ }^{27}$

Similar strategies have been employed to target other toxic gain of function ALS genes. Sustained ASO-mediated lowering of C9orf 2 RNA throughout the central nervous system of mice following an intrathecal (lateral ventricle) injection was found to be well tolerated. ${ }^{29}$ As it is currently unclear whether haploinsufficiency of $C 9$ orf 72 is relevant to the disease process in ALS, it remains unclear if using ASOs to lower C9orf 72 RNA is a viable treatment strategy. Currently, the only human ALS trial with ASOs is in SOD1, though this approach, particularly as more ALS genes are discovered.

\section{Cell-based treatments}

In addition to pharmacological treatments, several clinical trials use stem cell transplantation, with two main therapeutic concepts behind this approach. ${ }^{30}$ These concepts include the potential replacement of motor neurons lost during the disease process and neural protection by improving metabolic support of the diseased motor neurons.

\section{Neural stem cells}

During development, pluripotent embryonic stem cells (ESCs) give rise to specific multipotent progenitor cell populations ${ }^{31}$ including neural stem cells (NSCs), which differentiate into neurons, astrocytes, and oligodendrocytes. ${ }^{32}$ Human NSCs can be derived from human $\mathrm{ESCs}^{33}$ or isolated from fetal neurologic tissue. ${ }^{34}$ When grafted into rat spinal cord, they retain their ability to differentiate into motor neurons, which integrate into spinal circuits. ${ }^{35}$

NSCs may be useful for ALS treatment. Human motor neuron administration delayed disease onset and prolonged survival in mouse ${ }^{36}$ and rat $^{37}$ SOD $1^{693 A}$ ALS models. In a Phase I clinical trial, human NSCs (NSI-455RSC cells) ${ }^{38}$ were injected into the lumbar and/or cervical spinal cord without major adverse events or accelerated disease progression. ${ }^{39} \mathrm{~A}$ Phase II trial is in progress (NCT01730716). 


\section{Mesenchymal stem cells}

Multipotent mesenchymal stem cells (MSCs) differentiate into osteoblasts, adipocytes, chondrocytes, and myocytes. They do not naturally differentiate into neural lineages but can be induced to do so. ${ }^{40}$ They can be isolated from bone marrow, cord, or peripheral blood and are thus more easily available than ESCs and, depending on the source, may not require immunosuppression.

MSCs may be useful for ALS treatment as a delivery vehicle to the central nervous system. Intraventricular injection of MSCs overexpressing glucagon-like peptide 1, an antioxidant with neuroprotective property, improved survival in the SOD1 mouse model. ${ }^{41}$ Injection of human MSCs overexpressing growth factors into the musculature of SODI rats reduced neuromuscular junction denervation and delayed disease progression. ${ }^{42}$ A synergistic effect was observed in overexpression of both vascular endothelial growth factor and glial cell line-derived neurotrophic factor. ${ }^{43}$ Injections of unmodified MSCs have also shown benefits on survival and disease progression in the SOD1 mouse model, ${ }^{44}$ possibly due to endogenous production of neuroprotective factors, which improves motor neuron metabolic support. Human autologous MSCs can be differentiated into neurotrophic factor secreting cells. A recent study showed that injection of these cells intrathecally and intramuscularly in an ALS patient treated on a compassionate basis was safe and clinically beneficial. ${ }^{45} \mathrm{~A}$ Phase I/II study in Israel was completed but no study results have been published (NCT01777646).

Several ALS clinical trials assessed the safety of MSC transplantations into the spinal $\operatorname{cord}^{46,47}$ or brain of ALS patients. ${ }^{48,49}$ These injections were safe without a clear clinical benefit. Postmortem pathological analysis of patients' spinal cords showed more motor neurons and fewer degenerative ubiquitin deposits, suggesting neurotrophic activity in the grafted cells. ${ }^{49}$ Intrathecal MSC application has been shown to be safe via lumbar puncture ${ }^{50}$ as well as Ommaya reservoir. $^{51}$

Another approach utilizing MSCs is subcutaneous injection of granulocyte colony-stimulating factor to mobilize endogenous MSCs, with ${ }^{52}$ or without ${ }^{53}$ collection and reinfusion of peripheral blood stem cells. Long-term administration of granulocyte colony-stimulating factor is safe ${ }^{54}$ and leads to persistent mobilization of hematopoietic stem cells ${ }^{55}$ but has no effect on the disease course. ${ }^{56}$

\section{Olfactory ensheathing cells}

Mammalian olfactory neurons regenerate throughout life from a stem cell layer at the base of the epithelium ${ }^{57}$ and are enfolded and guided by olfactory ensheathing cells (OECs) in the olfactory bulb. ${ }^{58}$

Based on findings in rodent spinal cord injury models ${ }^{59}$ and spinal cord injury clinical trials, ${ }^{60}$ OECs were applied for ALS treatment. Spinal grafts showed increased survival of SOD1 rats and slowing of motor neuron loss. ${ }^{61}$ Before there was clear evidence of benefit in an animal model, a laboratory in People's Republic of China grafted OECs in ALS patients based on spinal cord injury clinical trials. ${ }^{62}$ OECs extracted from human fetal olfactory bulbs were injected into the bilateral corona radiata in 15 patients who were compared to 20 untreated controls. Over a 4-month follow-up period, a five-point difference in the ALS functioning rating scale-revised (ALSFRS-R) was detected. The study was halted as the authors felt there was "conclusive proof of positive and beneficial results". ${ }^{63}$ Simultaneously, this group enrolled 327 patients in a noncontrolled trial that compared injection of OECs into the spinal cord, the bilateral corona radiata, or both. They reported improved ALS functioning rating scale and normalized electromyographical findings 4 weeks after transplantation, with no differences between the three groups ${ }^{64}$ These results are largely contested and no further follow-ups were conducted. Despite this, hundreds of additional patients underwent OEC grafting in People's Republic of China based on these results, some with multiple injections. The authors reported improved ALS functioning rating scale after each injection but diminished response after repeated injections. ${ }^{65}$ Independent follow-up studies on patients who received OEC transplants in People's Republic of China could not confirm the reported observations. ${ }^{66}$ Postmortem studies did not suggest neuroprotection or axonal regeneration. ${ }^{67}$

\section{Induced pluripotent stem cells}

The discovery of induced pluripotent stem cells (iPSCs) showed that pluripotency can be induced in adult somatic mouse cells via introduction of transcription factors. ${ }^{68}$ Similarly, human iPSCs can be generated from human fibroblasts. ${ }^{69}$ iPSCs differ from human ESCs in gene expression and DNA methylation patterns but are germline-competent, ${ }^{70}$ generate all three germ layer cell types, ${ }^{71}$ and form active motor neurons..$^{72}$ The potential for iPSC technology is enormous as it allows for a limitless supply of autologous pluripotent cells that can be reintroduced into the patient without immunosuppression. However, the current knowledge about these cells and ability for clinical application is limited. ${ }^{73}$

iPSCs have several important potential applications in ALS. Neural progenitor cells derived from human iPSCs 
survived and showed neuronal phenotypes when grafted into the spinal cord of SOD1 rats. ${ }^{74}$ Intrathecal or tail vein cell injection in SOD1 mice significantly improved survival and neurological function. ${ }^{75}$ Transplantation of glial-restricted precursor cells derived from human iPSCs targets astrocytic dysfunction observed in ALS and prolongs the lifespan of SOD1 mice. ${ }^{76}$

Besides possible clinical applications, it is important to emphasize the role that iPSCs play in modeling diseases in vitro. Several groups used either iPSCs derived from ALS patients $^{77,78}$ or motor neurons derived from these iPSCs ${ }^{79,80}$ to further study ALS pathophysiology.

\section{Symptomatic treatment}

As the treatment options for ALS continue to be limited, symptomatic treatment is very important in the care of ALS patients. Specialized clinics provide multidisciplinary care by neurologists, specialty nurses, physical, occupational, respiratory, and speech therapists, dieticians, and social workers. The benefits of multidisciplinary clinics have been demonstrated in several studies, including survival ${ }^{81-83}$ and quality of life ${ }^{84}$ when compared to patients seen in general neurology clinics. Both American ${ }^{85}$ and European guidelines ${ }^{86}$ recommend multidisciplinary care.

\section{Dyspnea}

Dyspnea and respiratory compromise are common progressive symptoms, with several possible interventions. Respiratory muscle training is often recommended, but the evidence to support its benefit is limited. ${ }^{87}$ Noninvasive positive pressure ventilation (NIV) has been shown to not only improve quality of life ${ }^{88}$ but also prolong life, especially in patients without significant bulbar dysfunction and in those who are able to tolerate daily use of at least 4 hours. ${ }^{89,90}$ A potential additive to NIV is diaphragmatic pacing, especially in patients with bulbar symptoms, as the effectiveness of NIV correlates inversely with the severity of bulbar symptoms..$^{91}$ In diaphragmatic pacing, electrodes are implanted in each hemidiaphragm, helping to provide maximal contraction of the diaphragm. In an open-label pilot study, 16 patients were implanted and showed benefits on survival (when compared to historical controls) and quality of life (as sleep dysfunction was reduced).$^{92}$ Results of small follow-up studies have been mixed. ${ }^{93,94}$ Large, randomized controlled trials comparing NIV and diaphragmatic pacing are ongoing in the United States and Europe. ${ }^{95}$ Invasive ventilation remains another option to prolong survival. ${ }^{96}$ This is generally well tolerated ${ }^{97}$ but is rarely selected for a variety of reasons, including patient's wishes and difficulties in home care.

Medications including opiates and benzodiazepines can be helpful in symptomatic treatment of dyspnea and dyspnearelated anxiety. ${ }^{98}$

\section{Sialorrhea}

About $25 \%$ of patients with motor neuron disease suffer from sialorrhea due to pseudohypersalivation. ${ }^{99}$ The majority of the treatments used for sialorrhea in ALS patients have not been studied in randomized controlled trials so there are no clear guidelines. Anticholinergic medications are generally recommended first. ${ }^{85}$ There are several oral agents, including atropine, glycopyrrolate, and amitriptyline. Transdermal application of hyoscyamine or scopolamine has the advantage of a constant concentration of drug in the circulation. ${ }^{100}$ For patients with sialorrhea refractory to medical therapy, salivatory gland botulinum toxin injections are an option, which lead to a significant decrease in saliva volume ${ }^{101}$ and have been shown to improve quality of life. ${ }^{102}$ Another alternative for treatment of refractory sialorrhea is radiation therapy of salivary glands. ${ }^{103}$

\section{Respiratory secretions}

Management of respiratory secretions and thick mucus can additionally become a major issue. Thick mucus production can be a symptom of ALS, medication side effect, or due to dehydration. Following insurance of good hydration and adjustment of medications, specific medication treatments can be added including mucolytics like $N$-acetylcysteine. ${ }^{85}$ Cough-assist and suction devices can be used to reduce the difficulty many patients experience with clearing respiratory secretions. ${ }^{104}$ Besides improving quality of life, these interventions have the potential to reduce hospitalizations. ${ }^{105}$

\section{Dysarthria}

Dyspnea often coincides with dysarthria. Speech therapy along with assistive devices is recommended. ${ }^{85}$ Communication devices greatly improve the patients' mood and quality of life. $^{106}$

\section{Dysphagia and weight loss}

Nutrition management is another important goal in the treatment of ALS, as patients will develop dysphagia due to bulbar muscular weakness. In the early stages, this can be managed by modifying the consistency of food and fluids and teaching swallowing techniques. To ensure adequate nutrition and hydration as well as to stabilize weight loss, placement of a 
percutaneous endoscopic gastrostomy (PEG) tube is offered to many ALS patients with dysphagia. ${ }^{107}$ Nutritional status is an independent prognostic factor for survival in patients with ALS. ${ }^{108}$ However, there is inconclusive data whether placement of a PEG tube actually provides significantly improved nutrition, quality of life, or survival. ${ }^{109}$ For patient safety, a PEG tube should be placed before the patient's vital capacity falls below $50 \%$ of predicted, ${ }^{85}$ even if no significant dysphagia is present at that time, as post-PEG deaths have been associated with reduced vital capacity. ${ }^{107}$

\section{Muscular symptoms}

Muscle issues including progressive weakness, cramps, and spasticity are cardinal features of ALS. Regular exercise of moderate intensity is generally recommended and has been found to improve quality of life, although the long-term benefit is unclear. ${ }^{110}$ Muscular cramps are a common complaint of ALS patients in all stages of the disease. Despite a number of medications undergoing trials so far, there has been no evidence supporting any specific intervention for muscle cramps in ALS. ${ }^{111}$ In practice, baclofen and gabapentin are frequently used to treat these. Baclofen is also often used to treat spasticity and is equally effective as tizanidine. ${ }^{112}$

\section{Fatigue}

Fatigue can be debilitating and is a common symptom of ALS. It is often associated with malnutrition or early respiratory failure. Fatigue is a potential medication side effect of many medications including riluzole, ${ }^{85}$ and medication adjustment should be considered. Multiple factors contribute to poor sleep which should be addressed throughout the disease course, and particularly with new complaints of fatigue. Depression should also be considered, as it is a common cause of fatigue and can benefit from treatment. ${ }^{113}$ Modafinil has been shown to have a positive effect on fatigue and sleepiness. ${ }^{114,115}$

\section{Pseudobulbar affect}

Pseudobulbar affect manifests as sudden episodes of uncontrollable laughter or crying without a provoking stimulus and is common in ALS. Dextromethorphan/quinidine has been shown to be effective in reducing the frequency and severity of emotional lability. ${ }^{116}$ The combination is necessary as dextromethorphan is rapidly metabolized if administered alone; quinidine reduces the metabolism via CYP2D6 inhibition. This combination has been approved by the FDA for pseudobulbar affect in ALS and represents the second FDA-approved drug specifically for ALS.

\section{Summary}

ALS remains a progressive motor neuron disease with a mean survival of 2-5 years. Symptom-based management of ALS in the setting of multidisciplinary clinics remains the most important current treatment strategy for the individual patient, as no curative therapies exist. Two decades after the first publication on using riluzole for treatment in ALS, this remains the only FDA-approved disease-modifying therapy. A large number of studied drugs showed promising results in animal models but failed translation to the human patient. One of the many difficulties in finding a treatment is the lack of understanding of pathophysiology of ALS. Yet, we remain optimistic about the medication treatments in developmental stages.

Novel therapeutic approaches with ASOs and stem cells have yet to show clear efficacy in humans; however, these remain exciting future directions of the field. Both have promising results in rodent and primate models of ALS. Early human trials have confirmed the safety of several of the potential methods. Preclinical studies showed the most convincing results in studies using NSCs. However, MSCs are more frequently used as they are more readily available and can easily be harvested and reintroduced into the patient without necessary immunosuppression.

\section{Disclosure}

The authors report no conflicts of interest in this work.

\section{References}

1. Noonan CW, White MC, Thurman D, Wong LY. Temporal and geographic variation in United States motor neuron disease mortality, 1969-1998. Neurology. 2005;64(7):1215-1221.

2. Rowland LP, Shneider NA. Amyotrophic lateral sclerosis. N Engl J Med. 2001;344(22):1688-1700.

3. Renton AE, Chio A, Traynor BJ. State of play in amyotrophic lateral sclerosis genetics. Nat Neurosci. 2014;17(1):17-23.

4. Chiò A, Mora G, Calvo A, et al. Epidemiology of ALS in Italy: a 10-year prospective population-based study. Neurology. 2009;72(8): 725-731.

5. Strong MJ, Grace GM, Freedman M, et al. Consensus criteria for the diagnosis of frontotemporal cognitive and behavioural syndromes in amyotrophic lateral sclerosis. Amyotroph Lateral Scler. 2009;10(3): 131-146.

6. Rohrer JD, Isaacs AM, Mizlienska S, et al. C9orf72 expansions in frontotemporal dementia and amyotrophic lateral sclerosis. Lancet Neurol. 2015;14(3):291-301.

7. Morris HR, Waite AJ, Williams NM, Neal JW, Blake DJ. Recent advances in the genetics of the ALS-FTLD complex. Curr Neurol Neurosci Rep. 2012;12(3):243-250.

8. Siddique T, Nijhawan D, Hentati A. Molecular genetic basis of familial ALS. Neurology. 1996;47(4 Suppl 2):S27-S34. [discussion S34-S25].

9. Rosen DR, Siddique T, Patterson D, et al. Mutations in $\mathrm{Cu} / \mathrm{Zn}$ superoxide dismutase gene are associated with familial amyotrophic lateral sclerosis. Nature. 1993;362(6415):59-62. 
10. Robberecht W, Philips T. The changing scene of amyotrophic lateral sclerosis. Nat Rev Neurosci. 2013;14(4):248-264.

11. Sreedharan J, Blair IP, Tripathi VB, et al. TDP-43 mutations in familial and sporadic amyotrophic lateral sclerosis. Science. 2008;319(5870): $1668-1672$.

12. Kwiatkowski TJ Jr, Bosco DA, Leclerc AL, et al. Mutations in the FUS/TLS gene on chromosome 16 cause familial amyotrophic lateral sclerosis. Science. 2009;323(5918):1205-1208.

13. Renton AE, Majounie E, Waite A, et al; ITALSGEN Consortium. A hexanucleotide repeat expansion in C9ORF72 is the cause of chromosome 9p21-linked ALS-FTD. Neuron. 2011;72(2):257-268.

14. Majounie E, Renton AE, Mok K, et al; Chromosome 9-ALS/FTD Consortium, French Research Network on FTLD/FTLD/ALS, ITALSGEN Consortium. Frequency of the C9orf72 hexanucleotide repeat expansion in patients with amyotrophic lateral sclerosis and frontotemporal dementia: a cross-sectional study. Lancet Neurol. 2012; 11(4):323-330.

15. Kabashi E, Valdmanis PN, Dion P, et al. TARDBP mutations in individuals with sporadic and familial amyotrophic lateral sclerosis. Nat Genet. 2008;40(5):572-574.

16. Neumann M, Sampathu DM, Kwong LK, et al. Ubiquitinated TDP-43 in frontotemporal lobar degeneration and amyotrophic lateral sclerosis. Science. 2006;314(5796):130-133.

17. Al-Chalabi A, Leigh PN. Recent advances in amyotrophic lateral sclerosis. Curr Opin Neurol. 2000;13(4):397-405.

18. Bensimon G, Lacomblez L, Meininger V. A controlled trial of riluzole in amyotrophic lateral sclerosis. ALS/Riluzole Study Group. $N$ Engl J Med. 1994;330(9):585-591.

19. Bensimon G, Lacomblez L, Delumeau JC, et al; Riluzole/ALS Study Group II. A study of riluzole in the treatment of advanced stage or elderly patients with amyotrophic lateral sclerosis. J Neurol. 2002; 249(5):609-615.

20. Miller RG, Mitchell JD, Moore DH. Riluzole for amyotrophic lateral sclerosis (ALS)/motor neuron disease (MND). Cochrane Database Syst Rev. 2012;3:CD001447.

21. Perel P, Roberts I, Sena E, et al. Comparison of treatment effects between animal experiments and clinical trials: systematic review. BMJ. 2007;334(7586): 197.

22. Gurney ME, Pu H, Chiu AY, et al. Motor neuron degeneration in mice that express a human $\mathrm{Cu}, \mathrm{Zn}$ superoxide dismutase mutation. Science. 1994;264(5166):1772-1775.

23. Zhou H, Huang $\mathrm{C}$, Chen $\mathrm{H}$, et al. Transgenic rat model of neurodegeneration caused by mutation in the TDP gene. PLoS Genet. 2010; 6(3):e1000887.

24. Saxena S, Cabuy E, Caroni P. A role for motoneuron subtype-selective ER stress in disease manifestations of FALS mice. Nat Neurosci. 2009; 12(5):627-636.

25. Miller TM, Pestronk A, David W, et al. An antisense oligonucleotide against SOD1 delivered intrathecally for patients with SOD1 familial amyotrophic lateral sclerosis: a phase 1, randomised, first-in-man study. Lancet Neurol. 2013;12(5):435-442.

26. Southwell AL, Skotte NH, Bennett CF, Hayden MR. Antisense oligonucleotide therapeutics for inherited neurodegenerative diseases. Trends Mol Med. 2012;18(11):634-643.

27. Miller TR, Wetter JB, Jarvis MF, Bitner RS. Spinal microglial activation in rat models of neuropathic and osteoarthritic pain: an autoradiographic study using [3H]PK11195. Eur J Pain. 2013;17(5):692-703.

28. Smith RA, Miller TM, Yamanaka K, et al. Antisense oligonucleotide therapy for neurodegenerative disease. J Clin Invest. 2006;116(8): 2290-2296.

29. Lagier-Tourenne C, Baughn M, Rigo F, et al. Targeted degradation of sense and antisense C9orf72 RNA foci as therapy for ALS and frontotemporal degeneration. Proc Natl Acad Sci U SA. 2013;110(47): E4530-E4539.

30. Thomsen GM, Gowing G, Svendsen S, Svendsen CN. The past, present and future of stem cell clinical trials for ALS. Exp Neurol. 2014;262(pt B): $127-137$.
31. Kudoh T, Concha ML, Houart C, Dawid IB, Wilson SW. Combinatorial Fgf and Bmp signalling patterns the gastrula ectoderm into prospective neural and epidermal domains. Development. 2004;131(15): 3581-3592.

32. Ohtsuka T, Shimojo H, Matsunaga M, et al. Gene expression profiling of neural stem cells and identification of regulators of neural differentiation during cortical development. Stem Cells. 2011;29(11): $1817-1828$.

33. Okabe S, Forsberg-Nilsson K, Spiro AC, Segal M, McKay RD. Development of neuronal precursor cells and functional postmitotic neurons from embryonic stem cells in vitro. Mech Dev. 1996;59(1): $89-102$.

34. Wu YY, Mujtaba T, Rao MS. Isolation of stem and precursor cells from fetal tissue. Methods Mol Biol. 2002;198:29-40.

35. Yan J, Xu L, Welsh AM, et al. Extensive neuronal differentiation of human neural stem cell grafts in adult rat spinal cord. PLoS Med. 2007; 4(2):e39.

36. Lee HJ, Kim KS, Ahn J, Bae HM, Lim I, Kim SU. Human motor neurons generated from neural stem cells delay clinical onset and prolong life in ALS mouse model. PLoS One. 2014;9(5):e97518.

37. Xu L, Yan J, Chen D, et al. Human neural stem cell grafts ameliorate motor neuron disease in SOD-1 transgenic rats. Transplantation. 2006;82(7):865-875.

38. Guo X, Johe K, Molnar P, Davis H, Hickman J. Characterization of a human fetal spinal cord stem cell line, NSI-566RSC, and its induction to functional motoneurons. J Tissue Eng Regen Med. 2010;4(3): 181-193.

39. Feldman EL, Boulis NM, Hur J, et al. Intraspinal neural stem cell transplantation in amyotrophic lateral sclerosis: phase 1 trial outcomes. Ann Neurol. 2014;75(3):363-373.

40. Franco Lambert AP, Fraga Zandonai A, Bonatto D, Cantarelli Machado D, Pegas Henriques JA. Differentiation of human adipose-derived adult stem cells into neuronal tissue: does it work? Differentiation. 2009;77(3):221-228.

41. Knippenberg S, Thau N, Dengler R, Brinker T, Petri S Intracerebroventricular injection of encapsulated human mesenchymal cells producing glucagon-like peptide 1 prolongs survival in a mouse model of ALS. PLoS One. 2012;7(6):e36857.

42. Suzuki M, McHugh J, Tork C, et al. Direct muscle delivery of GDNF with human mesenchymal stem cells improves motor neuron survival and function in a rat model of familial ALS. Mol Ther. 2008;16(12): 2002-2010.

43. Krakora D, Mulcrone P, Meyer M, et al. Synergistic effects of GDNF and VEGF on lifespan and disease progression in a familial ALS rat model. Mol Ther. 2013;21(8):1602-1610.

44. Bigini P, Veglianese P, Andriolo G, et al. Intracerebroventricular administration of human umbilical cord blood cells delays disease progression in two murine models of motor neuron degeneration. Rejuvenation Res. 2011;14(6):623-639.

45. Petrou P, Argov A, Lennon VA, et al. Rare combination of myasthenia and motor neuronopathy, responsive to Msc-Ntf stem cell therapy. Muscle Nerve. 2014;49(3):455-457.

46. Mazzini L, Vercelli A, Ferrero I, Boido M, Cantello R, Fagioli F. Transplantation of mesenchymal stem cells in ALS. Prog Brain Res. 2012;201:333-359.

47. Deda H, Inci MC, Kürekçi AE, et al. Treatment of amyotrophic lateral sclerosis patients by autologous bone marrow-derived hematopoietic stem cell transplantation: a 1-year follow-up. Cytotherapy. 2009;11(1): $18-25$.

48. Martínez HR, Molina-Lopez JF, González-Garza MT, et al. Stem cell transplantation in amyotrophic lateral sclerosis patients: methodological approach, safety, and feasibility. Cell Transplant. 2012;21(9): 1899-1907.

49. Blanquer M, Moraleda JM, Iniesta F, et al. Neurotrophic bone marrow cellular nests prevent spinal motoneuron degeneration in amyotrophic lateral sclerosis patients: a pilot safety study. Stem Cells. 2012;30(6): $1277-1285$. 
50. Karussis D, Karageorgiou C, Vaknin-Dembinsky A, et al. Safety and immunological effects of mesenchymal stem cell transplantation in patients with multiple sclerosis and amyotrophic lateral sclerosis. Arch Neurol. 2010;67(10):1187-1194.

51. Baek W, Kim YS, Koh SH, et al. Stem cell transplantation into the intraventricular space via an Ommaya reservoir in a patient with amyotrophic lateral sclerosis. J Neurosurg Sci. 2012;56(3):261-263.

52. Cashman N, Tan LY, Krieger C, et al. Pilot study of granulocyte colony stimulating factor (G-CSF)-mobilized peripheral blood stem cells in amyotrophic lateral sclerosis (ALS). Muscle Nerve. 2008;37(5): 620-625.

53. Nefussy B, Artamonov I, Deutsch V, Naparstek E, Nagler A, Drory VE. Recombinant human granulocyte-colony stimulating factor administration for treating amyotrophic lateral sclerosis: a pilot study. Amyotroph Lateral Scler. 2010;11(1-2):187-193.

54. Grassinger J, Khomenko A, Hart C, et al. Safety and feasibility of long term administration of recombinant human granulocyte-colony stimulating factor in patients with amyotrophic lateral sclerosis. Cytokine. 2014;67(1):21-28.

55. Tarella C, Rutella S, Gualandi F, et al; STEMALS Study Group. Consistent bone marrow-derived cell mobilization following repeated short courses of granulocyte-colony-stimulating factor in patients with amyotrophic lateral sclerosis: results from a multicenter prospective trial. Cytotherapy. 2010;12(1):50-59.

56. Chio A, Mora G, La Bella V, et al. Repeated courses of granulocyte colony-stimulating factor in amyotrophic lateral sclerosis: clinical and biological results from a prospective multicenter study. Muscle Nerve. 2011;43(2):189-195.

57. Weiler E, Farbman AI. Proliferation in the rat olfactory epithelium: age-dependent changes. J Neurosci. 1997;17(10):3610-3622.

58. Ruitenberg MJ, Vukovic J, Sarich J, Busfield SJ, Plant GW. Olfactory ensheathing cells: characteristics, genetic engineering, and therapeutic potential. J Neurotrauma. 2006;23(3-4):468-478.

59. Ramon-Cueto A, Cordero MI, Santos-Benito FF, Avila J. Functional recovery of paraplegic rats and motor axon regeneration in their spinal cords by olfactory ensheathing glia. Neuron. 2000;25(2):425-435.

60. Mackay-Sim A, St John JA. Olfactory ensheathing cells from the nose: clinical application in human spinal cord injuries. Exp Neurol. 2011; 229(1):174-180.

61. Li Y, Bao J, Khatibi NH, et al. Olfactory ensheathing cell transplantation into spinal cord prolongs the survival of mutant SOD1(G93A) ALS rats through neuroprotection and remyelination. Anat Rec. 2011;294(5): 847-857.

62. Lunn JS, Sakowski SA, Feldman EL. Concise review: stem cell therapies for amyotrophic lateral sclerosis: recent advances and prospects for the future. Stem Cells. 2014;32(5):1099-1109.

63. Huang H, Chen L, Xi H, et al. Fetal olfactory ensheathing cells transplantation in amyotrophic lateral sclerosis patients: a controlled pilot study. Clin Transplant. 2008;22(6):710-718.

64. Chen L, Huang H, Zhang J, et al. Short-term outcome of olfactory ensheathing cells transplantation for treatment of amyotrophic lateral sclerosis. Zhongguo Xiu Fu Chong Jian Wai Ke Za Zhi. 2007;21(9): 961-966.

65. Chen L, Chen D, Xi H, et al. Olfactory ensheathing cell neurorestorotherapy for amyotrophic lateral sclerosis patients: benefits from multiple transplantations. Cell Transplant. 2012;21(Suppl 1):S65-S77.

66. Piepers S, van den Berg LH. No benefits from experimental treatment with olfactory ensheathing cells in patients with ALS. Amyotroph Lateral Scler. 2010;11(3):328-330.

67. Giordana MT, Grifoni S, Votta B, et al. Neuropathology of olfactory ensheathing cell transplantation into the brain of two amyotrophic lateral sclerosis (ALS) patients. Brain Pathol. 2010;20(4):730-737.

68. Takahashi K, Yamanaka S. Induction of pluripotent stem cells from mouse embryonic and adult fibroblast cultures by defined factors. Cell. 2006;126(4):663-676.

69. Takahashi K, Tanabe K, Ohnuki M, et al. Induction of pluripotent stem cells from adult human fibroblasts by defined factors. Cell. 2007;131(5):861-872.
70. Okita K, Ichisaka T, Yamanaka S. Generation of germline-competent induced pluripotent stem cells. Nature. 2007;448(7151):313-317.

71. Boulting GL, Kiskinis E, Croft GF, et al. A functionally characterized test set of human induced pluripotent stem cells. Nat Biotechnol. 2011;29(3):279-286.

72. Karumbayaram S, Novitch BG, Patterson M, et al. Directed differentiation of human-induced pluripotent stem cells generates active motor neurons. Stem Cells. 2009;27(4):806-811.

73. Yamanaka S. A fresh look at iPS cells. Cell. 2009;137(1):13-17.

74. Popescu IR, Nicaise C, Liu S, et al. Neural progenitors derived from human induced pluripotent stem cells survive and differentiate upon transplantation into a rat model of amyotrophic lateral sclerosis. Stem Cells Transl Med. 2013;2(3):167-174.

75. Nizzardo M, Simone C, Falcone M, et al. Direct reprogramming of adult somatic cells into other lineages: past evidence and future perspectives. Cell Transplant. 2013;22(6):921-944.

76. Kondo T, Funayama M, Tsukita K, et al. Focal transplantation of human iPSC-derived glial-rich neural progenitors improves lifespan of ALS mice. Stem Cell Rep. 2014;3(2):242-249.

77. Burkhardt MF, Martinez FJ, Wright S, et al. A cellular model for sporadic ALS using patient-derived induced pluripotent stem cells. Mol Cell Neurosci. 2013;56:355-364.

78. Chestkov IV, Vasilieva EA, Illarioshkin SN, Lagarkova MA, Kiselev SL. Patient-specific induced pluripotent stem cells for SOD1-associated amyotrophic lateral sclerosis pathogenesis studies. Acta Naturae. 2014; 6(1):54-60.

79. Dimos JT, Rodolfa KT, Niakan KK, et al. Induced pluripotent stem cells generated from patients with ALS can be differentiated into motor neurons. Science. 2008;321(5893):1218-1221.

80. Yao XL, Ye CH, Liu Q, et al. Motoneuron differentiation of induced pluripotent stem cells from SOD1G93A mice. PLoS One. 2013; 8(5):e64720.

81. Traynor BJ, Alexander M, Corr B, Frost E, Hardiman O. Effect of a multidisciplinary amyotrophic lateral sclerosis (ALS) clinic on ALS survival: a population based study, 1996-2000. J Neurol Neurosurg Psychiatry. 2003;74(9):1258-1261.

82. Chio A, Bottacchi E, Buffa C, Mutani R, Mora G; Parals. Positive effects of tertiary centres for amyotrophic lateral sclerosis on outcome and use of hospital facilities. J Neurol Neurosurg Psychiatry. 2006;77(8): 948-950.

83. Aridegbe T, Kandler R, Walters SJ, Walsh T, Shaw PJ, McDermott CJ. The natural history of motor neuron disease: assessing the impact of specialist care. Amyotroph Lateral Scler Frontotemporal Degener. 2013;14(1):13-19.

84. Van den Berg JP, Kalmijn S, Lindeman E, et al. Multidisciplinary ALS care improves quality of life in patients with ALS. Neurology. 2005; 65(8):1264-1267.

85. Miller RG, Jackson CE, Kasarskis EJ, et al; Quality Standards Subcommittee of the American Academy of Neurology. Practice parameter update: the care of the patient with amyotrophic lateral sclerosis: multidisciplinary care, symptom management, and cognitive/behavioral impairment (an evidence-based review): report of the Quality Standards Subcommittee of the American Academy of Neurology. Neurology. 2009;73(15):1227-1233.

86. EFNS Task Force on Diagnosis and Management of Amyotrophic Lateral Sclerosis; Andersen PM, Abrahams S, et al. EFNS guidelines on the clinical management of amyotrophic lateral sclerosis (MALS) - revised report of an EFNS task force. Eur J Neurol. 2012;19(3):360-375.

87. Eidenberger M, Nowotny S. Inspiratory muscle training in patients with amyotrophic lateral sclerosis: a systematic review. Neurorehabilitation. 2014;35(3):349-361.

88. Mustfa N, Walsh E, Bryant V, et al. The effect of noninvasive ventilation on ALS patients and their caregivers. Neurology. 2006;66(8): 1211-1217.

89. Bourke SC, Tomlinson M, Williams TL, Bullock RE, Shaw PJ, Gibson GJ. Effects of non-invasive ventilation on survival and quality of life in patients with amyotrophic lateral sclerosis: a randomised controlled trial. Lancet Neurol. 2006;5(2):140-147. 
90. Lo Coco D, Marchese S, Pesco MC, La Bella V, Piccoli F, Lo Coco A. Noninvasive positive-pressure ventilation in ALS: predictors of tolerance and survival. Neurology. 2006;67(5):761-765.

91. Sancho J, Servera E, Morelot-Panzini C, Salachas F, Similowski T, Gonzalez-Bermejo J. Non-invasive ventilation effectiveness and the effect of ventilatory mode on survival in ALS patients. Amyotroph Lateral Scler Frontotemporal Degener. 2014;15(1-2):55-61.

92. Onders RP, Elmo M, Kaplan C, Katirji B, Schilz R. Final analysis of the pilot trial of diaphragm pacing in amyotrophic lateral sclerosis with long-term follow-up: diaphragm pacing positively affects diaphragm respiration. Am J Surg. 2014;207(3):393-397. [discussion 397].

93. Gonzalez-Bermejo J, Morelot-Panzini C, Salachas F, et al. Diaphragm pacing improves sleep in patients with amyotrophic lateral sclerosis. Amyotroph Lateral Scler. 2012;13(1):44-54.

94. Mahajan KR, Bach JR, Saporito L, Perez N. Diaphragm pacing and noninvasive respiratory management of amyotrophic lateral sclerosis/ motor neuron disease. Muscle Nerve. 2012;46(6):851-855.

95. McDermott CJ, Maguire C, Cooper CL, et al. Protocol for diaphragm pacing in patients with respiratory muscle weakness due to motor neurone disease (DiPALS): a randomised controlled trial. BMC Neurol. 2012;12:74

96. Hayashi H, Oppenheimer EA. ALS patients on TPPV: totally lockedin state, neurologic findings and ethical implications. Neurology. 2003;61(1):135-137.

97. Sanjuan-Lopez P, Valino-Lopez P, Ricoy-Gabaldon J, VereaHernando H. Amyotrophic lateral sclerosis: impact of pulmonary follow-up and mechanical ventilation on survival. A study of 114 cases. Arch Bronconeumol. 2014;50(12):509-513.

98. Clemens KE, Klaschik E. Morphine in the management of dyspnoea in ALS. A pilot study. Eur J Neurol. 2008;15(5):445-450.

99. Young CA, Ellis C, Johnson J, Sathasivam S, Pih N. Treatment for sialorrhea (excessive saliva) in people with motor neuron disease/ amyotrophic lateral sclerosis. Cochrane Database Syst Rev. 2011;5: CD006981.

100. Banfi P, Ticozzi N, Lax A, Guidugli GA, Nicolini A, Silani V. A review of options for treating sialorrhea in amyotrophic lateral sclerosis. Respir Care. Epub September 16, 2014.

101. Jackson CE, Gronseth G, Rosenfeld J, et al; Muscle Study Group. Randomized double-blind study of botulinum toxin type B for sialorrhea in ALS patients. Muscle Nerve. 2009;39(2):137-143.

102. Verma A, Steele J. Botulinum toxin improves sialorrhea and quality of living in bulbar amyotrophic lateral sclerosis. Muscle Nerve. 2006;34(2):235-237.

103. Assouline A, Levy A, Abdelnour-Mallet M, et al. Radiation therapy for hypersalivation: a prospective study in 50 amyotrophic lateral sclerosis patients. Int J Radiat Oncol Biol Phys. 2014;88(3):589-595.

104. Mustfa N, Aiello M, Lyall RA, et al. Cough augmentation in amyotrophic lateral sclerosis. Neurology. 2003;61(9):1285-1287.

105. Vitacca M, Paneroni M, Trainini D, et al. At home and on demand mechanical cough assistance program for patients with amyotrophic lateral sclerosis. Am J Phys Med Rehabil. 2010;89(5):401-406.

106. Körner S, Sieniawski M, Kollewe K, et al. Speech therapy and communication device: impact on quality of life and mood in patients with amyotrophic lateral sclerosis. Amyotroph Lateral Scler Frontotemporal Degener. 2013;14(1):20-25.

107. Kasarskis EJ, Scarlata D, Hill R, Fuller C, Stambler N, Cedarbaum JM. A retrospective study of percutaneous endoscopic gastrostomy in ALS patients during the BDNF and CNTF trials. J Neurol Sci. 1999; 169(1-2):118-125.

108. Desport JC, Preux PM, Truong TC, Vallat JM, Sautereau D, Couratier P. Nutritional status is a prognostic factor for survival in ALS patients. Neurology. 1999;53(5):1059-1063.

109. Katzberg HD, Benatar M. Enteral tube feeding for amyotrophic lateral sclerosis/motor neuron disease. Cochrane Database Syst Rev. 2011;1 CD004030.

110. Bello-Haas VD, Florence JM, Kloos AD, et al. A randomized controlled trial of resistance exercise in individuals with ALS. Neurology. 2007;68(23):2003-2007.
111. Baldinger R, Katzberg HD, Weber M. Treatment for cramps in amyotrophic lateral sclerosis/motor neuron disease. Cochrane Database Syst Rev. 2012;4:CD004157.

112. Chou R, Peterson K, Helfand M. Comparative efficacy and safety of skeletal muscle relaxants for spasticity and musculoskeletal conditions: a systematic review. J Pain Symptom Manage. 2004;28(2): $140-175$

113. McDonald ER, Wiedenfeld SA, Hillel A, Carpenter CL, Walter RA. Survival in amyotrophic lateral sclerosis. The role of psychological factors. Arch Neurol. 1994;51(1):17-23.

114. Carter GT, Weiss MD, Lou JS, et al. Modafinil to treat fatigue in amyotrophic lateral sclerosis: an open label pilot study. Am J Hosp Palliat Care. 2005;22(1):55-59.

115. Rabkin JG, Gordon PH, McElhiney M, Rabkin R, Chew S, Mitsumoto H. Modafinil treatment of fatigue in patients with ALS a placebo-controlled study. Muscle Nerve. 2009;39(3):297-303.

116. Pioro EP, Brooks BR, Cummings J, et al; Safety, Tolerability, and Efficacy Results Trial of AVP-923 in PBA Investigators. Dextromethorphan plus ultra low-dose quinidine reduces pseudobulbar affect. Ann Neurol. 2010;68(5):693-702.

117. Meissner F, Molawi K, Zychlinsky A. Mutant superoxide dismutase 1-induced IL-1beta accelerates ALS pathogenesis. Proc Natl Acad Sci U S A. 2010;107(29):13046-13050.

118. Kalmar B, Edet-Amana E, Greensmith L. Treatment with a coinducer of the heat shock response delays muscle denervation in the SOD1G93A mouse model of amyotrophic lateral sclerosis. Amyotroph Lateral Scler. 2012;13(4):378-392.

119. Kalmar B, Novoselov S, Gray A, Cheetham ME, Margulis B, Greensmith L. Late stage treatment with arimoclomol delays disease progression and prevents protein aggregation in the SOD1 mouse model of ALS. J Neurochem. 2008;107(2):339-350.

120. Cudkowicz ME, Shefner JM, Simpson E, et al; Northeast ALS Consortium. Arimoclomol at dosages up to $300 \mathrm{mg}$ /day is well tolerated and safe in amyotrophic lateral sclerosis. Muscle Nerve. 2008;38(1):837-844.

121. Yan Q, Elliott J, Snider WD. Brain-derived neurotrophic factor rescues spinal motor neurons from axotomy-induced cell death. Nature. 1992;360(6406):753-755.

122. Novikov L, Novikova L, Kellerth JO. Brain-derived neurotrophic factor promotes survival and blocks nitric oxide synthase expression in adult rat spinal motoneurons after ventral root avulsion. Neurosci Lett. 1995;200(1):45-48.

123. Ikeda K, Klinkosz B, Greene T, et al. Effects of brain-derived neurotrophic factor on motor dysfunction in wobbler mouse motor neuron disease. Ann Neurol. 1995;37(4):505-511.

124. Bemelmans AP, Husson I, Jaquet M, Mallet J, Kosofsky BE, Gressens P. Lentiviral-mediated gene transfer of brain-derived neurotrophic factor is neuroprotective in a mouse model of neonatal excitotoxic challenge. J Neurosci Res. 2006;83(1):50-60.

125. A controlled trial of recombinant methionyl human BDNF in ALS: the BDNF Study Group (phase III). Neurology. 1999;52(7): 1427-1433.

126. Sendtner M, Kreutzberg GW, Thoenen H. Ciliary neurotrophic factor prevents the degeneration of motor neurons after axotomy. Nature. 1990;345(6274):440-441.

127. Bongioanni P, Reali C, Sogos V. Ciliary neurotrophic factor (CNTF) for amyotrophic lateral sclerosis/motor neuron disease. Cochrane Database Syst Rev. 2004;3:CD004302.

128. Rothstein JD, Patel S, Regan MR, et al. Beta-lactam antibiotics offer neuroprotection by increasing glutamate transporter expression. Nature. 2005;433(7021):73-77.

129. Cudkowicz ME, Titus S, Kearney M, et al; Ceftriaxone Study Investigators. Safety and efficacy of ceftriaxone for amyotrophic lateral sclerosis: a multi-stage, randomised, double-blind, placebo-controlled trial. Lancet Neurol. 2014;13(11):1083-1091.

130. Drachman DB, Frank K, Dykes-Hoberg M, et al. Cyclooxygenase 2 inhibition protects motor neurons and prolongs survival in a transgenic mouse model of ALS. Ann Neurol. 2002;52(6):771-778. 
131. Cudkowicz ME, Shefner JM, Schoenfeld DA, et al. Trial of celecoxib in amyotrophic lateral sclerosis. Ann Neurol. 2006;60(1):22-31.

132. Beal MF. Coenzyme Q10 as a possible treatment for neurodegenerative diseases. Free Radic Res. 2002;36(4):455-460.

133. Kaufmann P, Thompson JL, Levy G, et al; QALS Study Group. Phase II trial of CoQ10 for ALS finds insufficient evidence to justify phase III. Ann Neurol. 2009;66(2):235-244.

134. Klivenyi P, Ferrante RJ, Matthews RT, et al. Neuroprotective effects of creatine in a transgenic animal model of amyotrophic lateral sclerosis. Nat Med. 1999;5(3):347-350.

135. Pastula DM, Moore DH, Bedlack RS. Creatine for amyotrophic lateral sclerosis/motor neuron disease. Cochrane Database Syst Rev. 2010;6: CD005225.

136. Keep M, Elmer E, Fong KS, Csiszar K. Intrathecal cyclosporin prolongs survival of late-stage ALS mice. Brain Res. 2001;894(2):327-331.

137. Appel SH, Stewart SS, Appel V, et al. A double-blind study of the effectiveness of cyclosporine in amyotrophic lateral sclerosis. Arch Neurol. 1988;45(4):381-386.

138. Vieira FG, LaDow E, Moreno A, et al. Dexpramipexole is ineffective in two models of ALS related neurodegeneration. PLoS One. 2014;9(12): e91608.

139. Cudkowicz ME, van den Berg LH, Shefner JM, et al; EMPOWER Investigators. Dexpramipexole versus placebo for patients with amyotrophic lateral sclerosis (EMPOWER): a randomised, double-blind, phase 3 trial. Lancet Neurol. 2013;12(11):1059-1067.

140. Ito $\mathrm{H}$, Wate $\mathrm{R}$, Zhang J, et al. Treatment with edaravone, initiated at symptom onset, slows motor decline and decreases SOD1 deposition in ALS mice. Exp Neurol. 2008;213(2):448-455.

141. Abe K, Itoyama Y, Sobue G, et al; Edaravone ALS Study Group. Confirmatory double-blind, parallel-group, placebo-controlled study of efficacy and safety of edaravone (MCI-186) in amyotrophic lateral sclerosis patients. Amyotroph Lateral Scler Frontotemporal Degener. 2014;15(7-8):610-617.

142. Taylor CP. Mechanisms of action of gabapentin. Rev Neurol. 1997; 153(Suppl 1):S39-S45.

143. Gurney ME, Cutting FB, Zhai P, et al. Benefit of vitamin E, riluzole, and gabapentin in a transgenic model of familial amyotrophic lateral sclerosis. Ann Neurol. 1996;39(2):147-157.

144. Miller RG, Moore DH 2nd, Gelinas DF, et al; Western ALS Study Group. Phase III randomized trial of gabapentin in patients with amyotrophic lateral sclerosis. Neurology. 2001;56(7):843-848.

145. Angelov DN, Waibel S, Guntinas-Lichius O, et al. Therapeutic vaccine for acute and chronic motor neuron diseases: implications for amyotrophic lateral sclerosis. Proc Natl Acad Sci U SA. 2003;100(8): 4790-4795.

146. Haenggeli C, Julien JP, Mosley RL, et al. Therapeutic immunization with a glatiramer acetate derivative does not alter survival in G93A and G37R SOD1 mouse models of familial ALS. Neurobiol Dis. 2007;26(1):146-152.

147. Meininger V, Drory VE, Leigh PN, Ludolph A, Robberecht W, Silani V. Glatiramer acetate has no impact on disease progression in ALS at $40 \mathrm{mg} /$ day: a double-blind, randomized, multicentre, placebocontrolled trial. Amyotroph Lateral Scler. 2009;10(5-6):378-383.

148. Nagano I, Ilieva H, Shiote M, et al. Therapeutic benefit of intrathecal injection of insulin-like growth factor- 1 in a mouse model of amyotrophic lateral sclerosis. J Neurol Sci. 2005;235(1-2):61-68.

149. Lai EC, Felice KJ, Festoff BW, et al. Effect of recombinant human insulin-like growth factor-I on progression of ALS. A placebocontrolled study. The North America ALS/IGF-I Study Group. Neurology. 1997;49(6):1621-1630.

150. Sakowski SA, Schuyler AD, Feldman EL. Insulin-like growth factor-I for the treatment of amyotrophic lateral sclerosis. Amyotroph Lateral Scler. 2009;10(2):63-73.

151. Sorenson EJ, Windbank AJ, Mandrekar JN, et al. Subcutaneous IGF-1 is not beneficial in 2-year ALS trial. Neurology. 2008;71(22): $1770-1775$.
152. Meucci N, Nobile-Orazio E, Scarlato G. Intravenous immunoglobulin therapy in amyotrophic lateral sclerosis. J Neurol. 1996;243(2): $117-120$.

153. Casanovas A, Ribera J, Hukkanen M, Riveros-Moreno V, Esquerda JE. Prevention by lamotrigine, MK- 801 and $\mathrm{N}$ omega-nitro-L-arginine methyl ester of motoneuron cell death after neonatal axotomy. Neuroscience. 1996;71(2):313-325.

154. Eisen A, Stewart H, Schulzer M, Cameron D. Anti-glutamate therapy in amyotrophic lateral sclerosis: a trial using lamotrigine. Can J Neurol Sci. 1993;20(4):297-301.

155. Ryberg H, Askmark H, Persson LI. A double-blind randomized clinical trial in amyotrophic lateral sclerosis using lamotrigine: effects on CSF glutamate, aspartate, branched-chain amino acid levels and clinical parameters. Acta Neurol Scand. 2003;108(1):1-8.

156. Fornai F, Longone $\mathrm{P}$, Cafaro L, et al. Lithium delays progression of amyotrophic lateral sclerosis. Proc Natl Acad Sci U SA. 2008;105(6): 2052-2057.

157. Miller RG, Moore DH, Forshew DA, et al; WALS Study Group. Phase II screening trial of lithium carbonate in amyotrophic lateral sclerosis: examining a more efficient trial design. Neurology. 2011;77(10): 973-979.

158. UKMND-LiCALS Study Group; Morrison KE, Dhariwal S, et al. Lithium in patients with amyotrophic lateral sclerosis (LiCALS): a phase 3 multicentre, randomised, double-blind, placebo-controlled trial. Lancet Neurol. 2013;12(4):339-345.

159. Suchy J, Lee S, Ahmed A, Shea TB. Dietary supplementation with S-adenosyl methionine delays the onset of motor neuron pathology in a murine model of amyotrophic lateral sclerosis. Neuromolecular Med. 2010;12(1):86-97.

160. Orrell RW, Lane RJ, Ross M. A systematic review of antioxidant treatment for amyotrophic lateral sclerosis/motor neuron disease. Amyotroph Lateral Scler. 2008;9(4):195-211.

161. Van Den Bosch L, Tilkin P, Lemmens G, Robberecht W. Minocycline delays disease onset and mortality in a transgenic model of ALS. Neuroreport. 2002;13(8):1067-1070.

162. Gordon PH, Moore DH, Miller RG, et al; Western ALS Study Group. Efficacy of minocycline in patients with amyotrophic lateral sclerosis: a phase III randomised trial. Lancet Neurol. 2007;6(12): $1045-1053$.

163. Andreassen OA, Dedeoglu A, Klivenyi P, Beal MF, Bush AI. $\mathrm{N}$-acetyl-L-cysteine improves survival and preserves motor performance in an animal model of familial amyotrophic lateral sclerosis. Neuroreport. 2000;11(11):2491-2493.

164. Neuraltus. The Science: Targeting Neuroinflammation to Treat Neurodegenerative Diseases; 2013. Available from: http://www.neuraltus. com/pages/science.html2013.

165. Miller RG, Zhang R, Block G, et al. NP001 regulation of macrophage activation markers in ALS: a phase I clinical and biomarker study. Amyotroph Lateral Scler Frontotemporal Degener. 2014;15(7-8): 601-609.

166. Sunyach C, Michaud M, Arnoux T, et al. Olesoxime delays muscle denervation, astrogliosis, microglial activation and motoneuron death in an ALS mouse model. Neuropharmacology. 2012;62(7):2346-2352.

167. Lenglet T, Lacomblez L, Abitbol JL, et al; Mitotarget Study Group. A phase II-III trial of olesoxime in subjects with amyotrophic lateral sclerosis. Eur J Neurol. 2014;21(3):529-536.

168. Kelemen J, Hedlund W, Orlin JB, Berkman EM, Munsat TL. Plasmapheresis with immunosuppression in amyotrophic lateral sclerosis. Arch Neurol. 1983;40(12):752-753.

169. Wright PD, Huang M, Weiss A, et al. Screening for inhibitors of the SOD1 gene promoter: pyrimethamine does not reduce SOD1 levels in cell and animal models. Neurosci Lett. 2010;482(3):188-192.

170. Lange DJ, Andersen PM, Remanan R, Marklund S, Benjamin D. Pyrimethamine decreases levels of SOD1 in leukocytes and cerebrospinal fluid of ALS patients: a phase I pilot study. Amyotroph Lateral Scler Frontotemporal Degener. 2013;14(3):199-204. 
171. Waibel S, Reuter A, Malessa S, Blaugrund E, Ludolph AC. Rasagiline alone and in combination with riluzole prolongs survival in an ALS mouse model. J Neurol. 2004;251(9):1080-1084.

172. Van Damme P, Leyssen M, Callewaert G, Robberecht W, Van Den Bosch L. The AMPA receptor antagonist NBQX prolongs survival in a transgenic mouse model of amyotrophic lateral sclerosis. Neurosci Lett. 2003;343(2):81-84.

173. Tortarolo M, Grignaschi G, Calvaresi N, et al. Glutamate AMPA receptors change in motor neurons of SOD1G93A transgenic mice and their inhibition by a noncompetitive antagonist ameliorates the progression of amytrophic lateral sclerosis-like disease. J Neurosci Res. 2006;83(1):134-146.

174. Paizs M, Tortarolo M, Bendotti C, Engelhardt JI, Siklos L. Talampanel reduces the level of motoneuronal calcium in transgenic mutant SOD1 mice only if applied presymptomatically. Amyotroph Lateral Scler. 2011;12(5):340-344.

175. Pascuzzi RM, Shefner J, Chappell AS, et al. A phase II trial of talampanel in subjects with amyotrophic lateral sclerosis. Amyotroph Lateral Scler. 2010;11(3):266-271.

176. Traynor BJ, Bruijn L, Conwit R, et al. Neuroprotective agents for clinical trials in ALS: a systematic assessment. Neurology. 2006;67(1): 20-27.

177. Hwee DT, Kennedy A, Ryans J, et al. Fast skeletal muscle troponin activator tirasemtiv increases muscle function and performance in the B6SJL-SOD1G93A ALS mouse model. PLoS One. 2014;9(5): e96921.

178. Shefner JM, Watson ML, Meng L, Wolff AA; Neals/Cytokinetics STUDY Team. A study to evaluate safety and tolerability of repeated doses of tirasemtiv in patients with amyotrophic lateral sclerosis. Amyotroph Lateral Scler Frontotemporal Degener. 2013;14(7-8): 574-581.

179. Maragakis NJ, Jackson M, Ganel R, Rothstein JD. Topiramate protects against motor neuron degeneration in organotypic spinal cord cultures but not in G93A SOD1 transgenic mice. Neurosci Lett. 2003;338(2):107-110.
180. Cudkowicz ME, Shefner JM, Schoenfeld DA, et al; Northeast ALS Consortium. A randomized, placebo-controlled trial of topiramate in amyotrophic lateral sclerosis. Neurology. 2003;61(4):456-464.

181. Poesen K, Lambrechts D, Van Damme P, et al. Novel role for vascular endothelial growth factor (VEGF) receptor-1 and its ligand VEGF-B in motor neuron degeneration. J Neurosci. 2008;28(42):10451-10459.

182. Zheng C, Nennesmo I, Fadeel B, Henter JI. Vascular endothelial growth factor prolongs survival in a transgenic mouse model of ALS. Ann Neurol. 2004;56(4):564-567.

183. Dodge JC, Treleaven CM, Fidler JA, et al. AAV4-mediated expression of IGF-1 and VEGF within cellular components of the ventricular system improves survival outcome in familial ALS mice. Mol Ther. 2010;18(12):2075-2084.

184. Pronto-Laborinho AC, Pinto S, de Carvalho M. Roles of vascular endothelial growth factor in amyotrophic lateral sclerosis. Biomed Res Int. 2014;2014:947513.

185. Desnuelle C, Dib M, Garrel C, Favier A. A double-blind, placebocontrolled randomized clinical trial of alpha-tocopherol (vitamin E) in the treatment of amyotrophic lateral sclerosis. ALS riluzole-tocopherol Study Group. Amyotroph Lateral Scler Other Motor Neuron Disord. 2001;2(1):9-18.

186. Graf M, Ecker D, Horowski R, et al; German Vitamin E/ALS Study Group. High dose vitamin E therapy in amyotrophic lateral sclerosis as add-on therapy to riluzole: results of a placebo-controlled doubleblind study. J Neural Transm. 2005;112(5):649-660.

187. Wang H, O’Reilly ÉJ, Weisskopf MG, et al. Vitamin E intake and risk of amyotrophic lateral sclerosis: a pooled analysis of data from 5 prospective cohort studies. Am J Epidemiol. 2011;173(6): 595-602.
Orphan Drugs: Research and Reviews

\section{Publish your work in this journal}

Orphan Drugs: Research and Reviews is an international, peer-reviewed, open access journal publishing original research, reports, reviews and commentaries on all areas of the design and development of orphan drugs for the treatment of rare diseases through to clinical applications. Clinical outcomes, patient safety, and programs for the development and

\section{Dovepress}

effective, safe, and sustained use of medicines will be a feature of the journal. The manuscript management system is completely online and includes a very quick and fair peer-review system, which is all easy to use. Visit http://www.dovepress.com/testimonials.php to read real quotes from published authors 